\title{
Use of masks in public places in Poland during SARS-Cov-2 epidemic: a covert observational study
}

\author{
Maria Ganczak ${ }^{1 *}$ D, Oskar Pasek², Łukasz Duda - Duma², Dawid Świstara ${ }^{2}$ and Marcin Korzeń ${ }^{3}$
}

\begin{abstract}
Background: Face masks have been employed in the COVID-19 pandemic plans as a public and personal health control measure against the spread of SARS-CoV-2. In Poland, obligatory wearing of masks in public spaces was introduced on April 10th, 2020; a relaxation of previous universal measures was announced on May 29th, 2020, limiting use to indoor public places.

Objective: To assess use of masks or other protective devices in public spaces in Poland during the SARS-Cov-2 epidemic.

Methods: A non-participatory covert observational study was conducted on three dates, (10.05/18.05/25.05.2020) at public spaces in 13 regions with different risks. Ten consecutive individuals were observed by each of 82 medical students ( $n=2460$ observations), using a structured checklist.

Results: Among 2353 observed persons, the female/male ratios were 1.0, 1.1, and 1.0 on the three dates. Almost three quarters - $73.6 \%(n=552 / 750)$ were using masks on date $1,66.5 \%(544 / 818)$ on date 2 ; and $65.7 \%(516 / 785)$ on date 3. Cloth masks predominated on all dates (64.7-62.3\%-62.6\%), followed by medical (23.4-28.5\%-26.9\%). Being female ( $\mathrm{OR}=1.77-1.47-1.53$ respectively) and location in a closed space $(\mathrm{OR}=2.60-2.59-2.32)$ were each associated with higher usage. Participants in sports were about two times less likely to use masks $(O R=0.64-0.53-$ $0.53)$ as compared to other activities. The proportion using masks correctly decreased gradually over time (364/552; 65.9\%; 339/544; 62.3\% and 304/516; 58.9\%). More females wore masks correctly (date 1: 205/294; 69.7\% vs 159/258; $61.6 \%$, and date $3: 186 / 284 ; 65.5 \%$ vs $118 / 232 ; 50.9 \% ; p=0.045 ; p=0.0008$ respectively). Uncovered noses (47.3$52.7 \%)$ and masks around the neck (39.2-42.6\%) were the most frequent incorrect practices.

Conclusions: Practices were not in line with official recommendations, especially among males, and deteriorated over time. Cloth masks were predominantly used in public spaces. Health promotion, through utilizing all available communication channels, would be helpful to increase compliance.
\end{abstract}

Keywords: SARS-Cov-2, Face mask, General population, Determinants

\footnotetext{
*Correspondence: m.ganczak@cm.uz.zgora.pl

'Department of Infectious Diseases, Collegium Medicum, Uniwersytet Zielonogórski, Zielona Góra, Poland

Full list of author information is available at the end of the article
}

(c) The Author(s). 2021 Open Access This article is licensed under a Creative Commons Attribution 4.0 International License, which permits use, sharing, adaptation, distribution and reproduction in any medium or format, as long as you give appropriate credit to the original author(s) and the source, provide a link to the Creative Commons licence, and indicate if changes were made. The images or other third party material in this article are included in the article's Creative Commons licence, unless indicated otherwise in a credit line to the material. If material is not included in the article's Creative Commons licence and your intended use is not permitted by statutory regulation or exceeds the permitted use, you will need to obtain permission directly from the copyright holder. To view a copy of this licence, visit http://creativecommons.org/licenses/by/4.0/ The Creative Commons Public Domain Dedication waiver (http://creativecommons.org/publicdomain/zero/1.0/) applies to the data made available in this article, unless otherwise stated in a credit line to the data. 


\section{Introduction}

The severe acute respiratory syndrome coronavirus 2 (SARS-COV-2) pandemic that begun in the Chinese province of Hubei quickly became a global threat [1]. As of December 1st 2020, the virus has infected more than 62.8 million individuals worldwide and caused almost 1.5 million deaths [2]. With no effective pharmacological interventions or universal access to the vaccine, other modes of prevention are the best approaches to control the disease spread $[3,4]$.

Strategies to transition out of lockdown $[5,6]$, carried out in many countries, need to take into account both symptomatic and asymptomatic individuals in spreading SARSCoV-2 from person-to-person through close contact [7, 8]. Protective equipment measures are needed $[9,10]$.

Either disposable surgical masks or reusable cotton ones are protective. Wearing masks in public places is seen as an important contribution to containing viral spread, especially when physical distancing is not possible or unpredictable [10]. Locations include stores and other shopping areas, workplaces, health care facilities (i.e. surgeries, hospitals, care-homes etc.), public transport, busy sidewalks, and households. If used widely and corresponding to risk, masks can reduce viral transmission. Benefits increase where exposure risk is high and are marginal where it is low $[9,10]$.

In the beginning of the pandemic, mask-wearing was controversial among leading health organizations, such as the World Health Organization (WHO) [11]. However, convinced by the evidence, the WHO has broadened its recommendations for use during the pandemic since June 5th, 2020 and advises that in areas where the virus is spreading, people should wear masks when social distancing is not possible $[12,13]$. The US Centers for Disease Control and Prevention (CDC) has also modified previous recommendations, suggesting that, together with infected persons and health care workers, healthy people "should wear cloth face coverings in public settings when around people outside of their household" [14, 15].

The European Centre for Disease Control (ECDC) recommends use in the community, especially when visiting busy, closed spaces [16]. Formal guidance from the ECDC has informed official advice in many countries. As more was understood about asymptomatic transmission, governments were more inclined to mandate wearing and facilitate access. The latter was possible through various initiatives such as the provision of templates or instructions for citizens on how to make cloth masks at home, together with boosting domestic production or access to shops selling fabric and in supermarkets [17].

Different regulations have been in place in central Europe since the epidemic began, including Poland, Slovakia and Czechia [17, 18]. In many countries wearing became mandatory outside the home as part of physical distancing measures under lockdowns. In some other countries masks have been introduced as part of transition measures universally or in certain circumstances, such as on public transport or where physical distancing is not possible. In remaining countries, wearing is recommended, but not mandatory, as part of transitional measures [17].

In Poland, obligatory mask wearing was not introduced in the initial phase of the pandemic. On April $10^{\mathrm{h}}, 2020,6$ weeks after the country's first laboratory confirmed SARS-Cov-2 case had been reported, a new control measure was announced [19]. It became obligatory to cover one's nose and mouth in public spaces; any form of face covering was acceptable [18]. A relaxation of previous universal measures regarding wearing masks was announced on May 29th, 2020, limiting use to shopping areas, health care facilities, care-homes, public transport and churches [19]. The obligation to wear masks in indoor and outdoor public spaces has been restored since October 10th, 2020 [20].

Reports on use of masks by the general public as a preventive measure to limit transmission are scant, especially in European countries. Therefore, the objective of this study was to assess use of masks or other protective devices in public spaces in Poland during the epidemic and to evaluate influencing determinants.

\section{Methods}

In Poland, mandatory face covering in public spaces was introduced in the beginning of April, 2020 [18]. In the end of May, 2020, it was limited to indoor public spaces [19]. A non-participatory covert observational study was carried out during three occasions over a period of three consecutive weeks (10.05.2020, 18.05.2020, 25.05.2020) among the general public in Poland from the different risk areas regarding SARS-Cov-2 pandemic. The risk classification was adapted from a report made by the Ministry of Health on basic reproductive number $(R)$ estimates [21]: high-risk areas $(\mathrm{R}>1)$; low-risk areas ( $\mathrm{R}$ $0.5-1.0)$; very low-risk areas $(\mathrm{R}<0.5)$.

According to the latest census, Poland has a population of 38,383,000 [22]. The representative target sample size needed to achieve the study objectives and sufficient statistical power was calculated with a sample size calculator [23]. This arrived at 664 participants, using a margin of error of $\pm 5 \%$, a confidence level (CI) of $99 \%$ and a $50 \%$ response distribution.

At $2 \mathrm{pm}$, at each time point described above, eighty two 4th year medical students observed ten consecutive individuals of $>4$ years of age while venturing out into public spaces (820 observations per time point) which were divided into two categories: open/enclosed space. The age frame $>4$ years was arbitrarily chosen due to 
the governmental regulation requiring mask use for children older than 4 years and adults [18]. Two types of public spaces were chosen arbitrarily: 1. representing open space, i.e. "sidewalks/parks" and 2. representing enclosed space - "shopping centers". Three activities were observed: walking, outdoor sport activities and shopping. Students were randomly selected to make observations outdoors ( $75 \%$ observations) and indoors (25\% observations). All 4th year medical students from the University of Zielona Gora, Poland, participated in the study collecting the relevant data. Trained students used a validated structured checklist, as recommended by "WHO guidelines on the use of masks in the context of COVID-19" [24]. Rational use of a mask was defined as wearing a specific type of mask (N95 respirator, medical mask, cloth mask, face shield or other - a scarf/ bidon). The correct manner of masks use in the public was defined as the use of masks as per the WHO/ECDC guidelines [16, 24]. Observations were carried out in student residence locations without the knowledge of those observed (covert).

\section{Statistical analysis}

Field notes were taken at observation points. Next, data were entered to MS Excel 2013. Data quality was assured by the review of data completeness by the research team (OP and MG). Data were validated using STATISTICA PL Version 12.5 (StatSoft Inc., 2016). Our main outcome was mask usage. For socio-demographic variables, gender was coded as one for males, and two for females. A place of residence variable was arbitrarily divided into 2 categories: a city up to 50,000 citizens and $>50,000$ citizens; a region regarding pandemic risk - into: high-risk $(\mathrm{R}>1)$ and low-risk/very low-risk areas $(\mathrm{R} \leq 1.0)$; a type of activity observed - into playing sports/other activities. A bivariate analysis assessed the demographic characteristics (gender, residency and region regarding pandemic risk), together with the participant location during the observation (open/closed space), and the type of activity observed, associated with the outcome variable. The categorical variable groups were compared using the chisquare test with Yates correction and Fisher's exact test. For observations made at each of the 3 time points, standard single-outcome logistic regression models were built for the predicted outcome variable (mask usage); all models were then reduced by the use of a stepwise selection and a backward procedure [25] with the help of $\mathrm{R}$ software [26]. Unstandardized regression coefficients in the regression model were used to assess any change in the model. A change in coefficients was compared and used to determine any variable change. For binary data the exponent of the coefficient is interpreted as the odds ratio (OR) [27].

\section{Results}

General characteristics of study participants by time point The general characteristics of study participants by each time point is presented in Table 1 . Seven medical students were on a sick leave at the first time point and three at the third, which limited the observations

Table 1 Respondent characteristics and mask usage by selected variables at three time points. Poland 2020; $n=750-818$

\begin{tabular}{|c|c|c|c|c|c|c|c|c|c|c|c|c|c|c|c|c|}
\hline \multirow[t]{3}{*}{ Variable } & & \multicolumn{5}{|c|}{11.05} & \multicolumn{5}{|c|}{18.05} & \multicolumn{5}{|c|}{25.05} \\
\hline & & \multicolumn{2}{|c|}{ Total } & \multicolumn{3}{|c|}{ Mask usage } & \multicolumn{2}{|c|}{ Total } & \multicolumn{3}{|c|}{ Mask usage } & \multicolumn{2}{|c|}{ Total } & \multicolumn{3}{|c|}{ Mask usage } \\
\hline & & $\begin{array}{l}N^{a} \\
750\end{array}$ & $\%$ & $\mathbf{n}$ & $\%$ & $p$ & $\begin{array}{l}N^{a} \\
818\end{array}$ & $\%$ & $\mathbf{n}$ & $\%$ & $p$ & $\begin{array}{l}N^{a} \\
785\end{array}$ & $\%$ & $\mathbf{n}$ & $\%$ & $p$ \\
\hline \multirow[t]{2}{*}{ Gender } & Female & 371 & $49.5 \%$ & 294 & $79.2 \%$ & 0.0005 & 434 & $53.1 \%$ & 318 & $73.3 \%$ & $<0.0001$ & 398 & $50.7 \%$ & 284 & $71.4 \%$ & 0.0008 \\
\hline & Male & 379 & $50.5 \%$ & 258 & $68.1 \%$ & & 384 & $46.9 \%$ & 226 & $58.9 \%$ & & 387 & $49.3 \%$ & 232 & $59.9 \%$ & \\
\hline \multirow[t]{2}{*}{ Residence } & $\begin{array}{l}\text { Town } \leq 50,000 \\
\text { inhabitants }\end{array}$ & 395 & $52.7 \%$ & 302 & $40.3 \%$ & 0.06 & 445 & $54.4 \%$ & 296 & $36.2 \%$ & 0.99 & 387 & $49.3 \%$ & 264 & $33.6 \%$ & 0.15 \\
\hline & $\begin{array}{l}\text { Town }>50,000 \\
\text { inhabitants }\end{array}$ & 355 & $47.3 \%$ & 250 & $33.3 \%$ & & 373 & $45.6 \%$ & 248 & $30.3 \%$ & & 398 & $50.7 \%$ & 252 & $32.1 \%$ & \\
\hline \multirow[t]{3}{*}{ Region } & $\mathrm{R}^{\mathrm{b}}<0.5$ & 220 & $29.3 \%$ & 160 & $72.7 \%$ & $>0.65$ & 269 & $32.9 \%$ & 164 & $61.0 \%$ & $>0.004$ & 277 & $35.3 \%$ & 171 & $61.7 \%$ & $>0.055$ \\
\hline & R $0.5-1.0$ & 410 & $54.7 \%$ & 302 & $73.7 \%$ & & 428 & $52.3 \%$ & 306 & $71.5 \%$ & & 389 & $49.6 \%$ & 268 & $68.9 \%$ & \\
\hline & $R>1.0$ & 120 & $16.0 \%$ & 90 & $75.0 \%$ & & 121 & $14.8 \%$ & 74 & $61.2 \%$ & & 119 & $15.2 \%$ & 77 & $64.7 \%$ & \\
\hline \multirow[t]{2}{*}{ Observation } & Open space & 578 & $78.1 \%$ & 407 & $70.4 \%$ & $<0.0001$ & 585 & $73.5 \%$ & 359 & $61.4 \%$ & $<0.0001$ & 577 & $74.5 \%$ & 351 & $60.8 \%$ & $<0.0001$ \\
\hline & Closed space & 162 & $21.9 \%$ & 141 & $87.0 \%$ & & 211 & $26.5 \%$ & 179 & $84.8 \%$ & & 198 & $25.5 \%$ & 159 & $80.3 \%$ & \\
\hline \multirow[t]{3}{*}{ Activity $^{a}$} & Walking & 353 & $51.5 \%$ & 261 & $73.9 \%$ & $<0.0001$ & 351 & $47.4 \%$ & 235 & $67.0 \%$ & $<0.0001$ & 368 & $50.7 \%$ & 243 & $66.0 \%$ & $<0.0001$ \\
\hline & Playing sports & 154 & $22.4 \%$ & 97 & $63.0 \%$ & & 170 & $23.0 \%$ & 91 & $53.5 \%$ & & 150 & $20.7 \%$ & 73 & $48.7 \%$ & \\
\hline & Shopping & 179 & $26.1 \%$ & 152 & $84.9 \%$ & & 219 & $29.6 \%$ & 179 & $81.7 \%$ & & 208 & $28.7 \%$ & 167 & $80.3 \%$ & \\
\hline
\end{tabular}

athe number is smaller than the number of the total observations due to the difficulties in classifications

${ }^{b}$ basic reproductive number 
number to 750 on May 11th and to 785 on May 25th. As some observations were excluded due to incomplete data, the total number of observations was 2353 (range: $750-818)$. The female/male ratio was similar (1.02; 1.13 and 1.03) at the 3 time points; this was similar to that observed in the general population (1.07) [22]. At each time point, the number of observations made in the open space was similar (78.1, 73.5 and 74.5\%); "walking" was the most common activity (51.5, 47.4 and 50.7\%), followed by "shopping" and "playing sports".

\section{Mask usage determinants by time point}

The percentage of those using masks was $73.6 \%$ (552/ $750)$ at the first time point, decreasing a week later (66.5\%; 544/818) and then -2 weeks later (65.7\%; 516/ 785). Table 1 and Fig. 1 present masks usage by the public at the three time points by selected variables.

Significantly more females than males used masks $(p<$ 0.01 for the three time points). A decreasing trend was observed in relation to mask use at three time points for both: the general public and females. In the case of males, a decrease in usage was seen during the second observation ( $68.1 \%$ vs $58.9 \%)$, however, the percentage of those using masks increased slightly (59.9\%) a week later.

Masks usage in both - enclosed and open space decreased among study participants during the 3-week observation $(87.0,84.8,80.3$, and $70.4 \%, 61.4,60.8 \%$ at the 3 consecutive time points). A statistically significant difference $(p<0.01)$ was observed between masks use in the open/enclosed locations at the three time points; Table 1, Fig. 1.

The percentage of people wearing masks at three time points in relation to the activity performed is presented at Table 1 and Fig. 1. The compliance with mask use was the highest while shopping (84.9\%; 81.7 and 80.3\%) and the lowest during outdoor sport activity (63\%; 53.5 and $48.7 \%)$. A statistically significant difference was observed in masks usage between activities at the three time points $(p \leq 0.01)$. The decrease of mask usage over time was more evident among those in sports than among the other activities.

As reported in Table 1, at the 2nd time point those living in low risk areas ( $\mathrm{R}$ 0.5-1.0) were more compliant regarding masks usage compared to regions with higher $(\mathrm{R}>1.0)$ and very low $(\mathrm{R}<0.5)$ pandemic risk $(p=$ $0.004)$. There were no statistically significant differences observed in masks usage at any of three time points $(p>$ $0.05)$ regarding the place of residence.

Multiple logistic regression analysis showed that participant gender, location during the observation and type of activity were independent predictors for mask usage (Table 2). Females were more likely to wear masks (for 3 time points: $\mathrm{OR}=1.77 ; \mathrm{OR}=1.47 ; \mathrm{OR}=1.53, p=0.002$; $p=0.03 ; p=0.01$ respectively). Participants observed in the closed spaces were more likely to use masks than those outdoors $(\mathrm{OR}=2.60 ; \mathrm{OR}=2.59 ; \mathrm{OR}=2.32, p=$ 0.0006; $p<0.0001 ; p<0.0001$ respectively). Interestingly, participants in sports were about two times less likely to use masks as compared to other activities. $(\mathrm{OR}=0.64$; $\mathrm{OR}=0.54 ; \quad \mathrm{OR}=0.54, \quad p=0.03 ; p=0.0007 ; p=0.001$ respectively).

\section{Correct mask usage over time}

The proportion using masks correctly decreased gradually over time $(65.9 \% ; 364 / 552,62.3 \% ; 339 / 544$ and $58.9 \% ; 304 / 516$ respectively). A statistically significant between-gender difference was noted in the 1st and 3rd week of observation, with more females wearing masks correctly (1st week: 205/294; 69.7\% vs $159 / 258$; 61.6\%, 2nd week: $197 / 318 ; 61.9 \%$ vs $142 / 226 ; 62.8 \%$ and 3 rd week: $186 / 284 ; 65.5 \%$ vs $118 / 232 ; 50.9 \% ; p=0.045 ; p=$ $0.83 ; p=0.0008$ respectively). The differences in the correct manner of masks use were not significant regarding location and activity $(p>0.05)$.
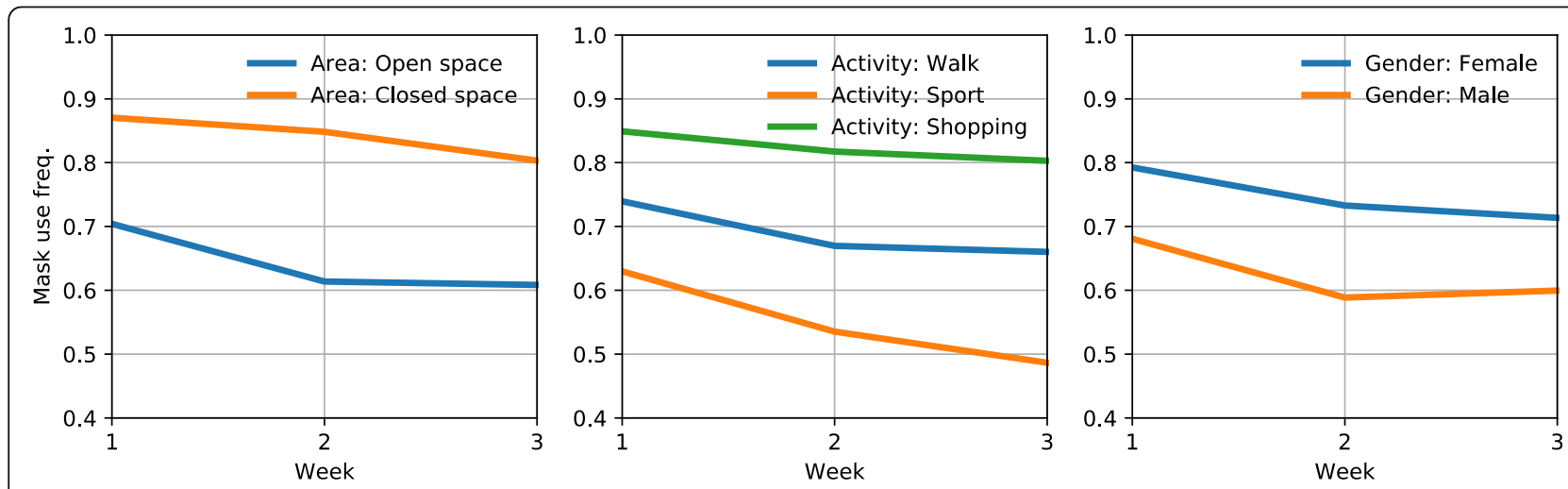

Fig. 1 Masks usage trend by area, activity and gender. Poland, 2020; $n=750-818$ 
Table 2 Logistic regression model: association of the mask usage with selected variables by time point (odds ratio (OR) estimates and 95\% confidence intervals (Cls) of OR estimates); Poland, 2020; $n=750-818$

\begin{tabular}{|c|c|c|c|c|c|c|}
\hline \multirow[t]{2}{*}{ Variable } & \multicolumn{2}{|c|}{ Time point 1} & \multirow{2}{*}{$\begin{array}{l}\text { Time point } 2 \\
\text { OR }\end{array}$} & \multicolumn{3}{|c|}{ Time point 3} \\
\hline & $\overline{\mathrm{OR}^{\mathrm{a}}}$ & $\mathrm{Cl}$ & & $\mathrm{Cl}$ & OR & $\mathrm{Cl}$ \\
\hline Gender: female & 1.77 & $1.24-2.53$ & 1.47 & $1.05-2.00$ & 1.53 & $1.07-2.12$ \\
\hline Area: closed space & 2.60 & $1.54-4.58$ & 2.59 & $1.69-4.06$ & 2.32 & $1.54-3.59$ \\
\hline Activity: sport & 0.64 & $0.43-0.97$ & 0.54 & $0.36-0.76$ & 0.54 & $0.36-0.78$ \\
\hline
\end{tabular}

${ }^{\mathrm{a}}$ Odds ratio $(\mathrm{OR})=$ ratio between the two categories tested in each variable, controlling for other variable

\section{Type of mask used}

A predominance of cloth masks was observed at all 3 time points followed by medical masks (Table 3); face shields were the type of face protection used the rarest.

The correct manner of mask use by type and time point is presented in Table 3. During the 1st week, $80.0 \%$ were correctly wearing N95 respirator mask with an increased correct use in the 2nd and 3rd week (83.3 and 94.4\%). An opposite trend had been observed for medical and home-made masks: $64.3 \%$; $65.8 \%$; 60.4 and $64.7 \%$; $60.2 \%$; $54.5 \%$ respectively were using those masks at the 1st, 2nd and 3rd week. There was not statistically significant between-type difference found at the 1st and 2nd time point regarding the correct wearing of a given type of a mask $(p>0.11)$; however, more participants used N95 respirators correctly when compared to other types of masks $(p=0.0008)$ at the 3 rd time point. At all 3 time points uncovered noses $(89 / 188 ; 47.3 \%, 108 / 205$; $52.7 \%$ and $106 / 212 ; 50 \%$ ) and masks around the neck (80/188; $42.6 \%, 85 / 205 ; 41.5 \%$ and $83 / 212 ; 39.2 \%$ ) were the most common incorrect practices, followed by touching masks by hands $(9 / 188 ; 4.8 \%, 8 / 205 ; 3.9 \%$ and $14 / 212 ; 6.6 \%)$ and incorrect mask fixation $(8 / 188 ; 4.3 \%$, $4 / 205 ; 2 \%$ and $9 / 212 ; 4.2 \%$ ).

\section{Discussion}

\section{Results overview}

Overall, compliance with wearing masks by the general public in Poland was good in the beginning of the study period (74\%), however, it decreased (to 66\%) in the 2nd and 3rd week of the observation, with a predominance of cloth masks observed. Female gender and closed space were each associated with higher mask usage. Those playing sports had about two times lower chance to use masks. The percentage of those using masks in the correct manner also decreased gradually over time, mainly due to a decreasing trend observed for medical and cloth masks; significantly more females correctly used masks. Breaches in nose covering and hanging masks around the neck were the most common incorrect practices while wearing a mask.

\section{Trends in mask use}

The willingness of the general public plays a decisive role in achieving the successful implementation of protective measures [3]. However, it is still a problem to encourage the public to unconditionally and continuously follow these recommended preventive actions.

The study found that in May 2020, when wearing masks in public spaces was compulsory in Poland, face covering was relatively high (74\%). According to Ipsos [28], in the initial phase of the pandemic (a week after the first case had been reported in Poland), only $4 \%$ of randomly selected Poles reported wearing masks in public settings to protect from coronavirus. Two weeks later, the percentage had increased 5 -fold. Five weeks later, 2 weeks after it became obligatory to cover one's nose and mouth in public in Poland, $78 \%$ of respondents stated they used masks "always" or "sometimes".

Concerns about the pandemic, combined with the perceived risk of infection may explain the high rates of masks use in our study. The strong association between respondents' risk perceptions and taking comprehensive precautionary measures against influenza, Middle East

Table 3 Frequency of mask usage by type of mask used and time point; Poland, 2020; $n=750-818$

\begin{tabular}{|c|c|c|c|c|c|c|c|c|c|c|c|c|}
\hline \multirow{3}{*}{$\begin{array}{l}\text { Type of } \\
\text { mask }\end{array}$} & \multicolumn{4}{|c|}{11.05} & \multicolumn{4}{|c|}{18.05} & \multicolumn{4}{|c|}{25.05} \\
\hline & \multicolumn{2}{|c|}{ Usage } & \multicolumn{2}{|c|}{ Correct usage } & \multicolumn{2}{|c|}{ Usage } & \multicolumn{2}{|c|}{ Correct usage } & \multicolumn{2}{|c|}{ Usage } & \multicolumn{2}{|c|}{ Correct usage } \\
\hline & $\mathrm{n}$ & $\%$ & $n$ & $\%$ & $n$ & $\%$ & $\mathrm{n}$ & $\%$ & $n$ & $\%$ & $\mathrm{n}$ & $\%$ \\
\hline Cloth mask & 357 & $64.7 \%$ & 231 & $64.7 \%$ & 339 & $62.3 \%$ & 204 & $60.2 \%$ & 323 & $62.6 \%$ & 176 & $54.5 \%$ \\
\hline Medical mask & 129 & $23.4 \%$ & 83 & $64.3 \%$ & 155 & $28.5 \%$ & 102 & $65.8 \%$ & 139 & $26.9 \%$ & 84 & $60.4 \%$ \\
\hline N95 respirator & 20 & $3.6 \%$ & 16 & $80.0 \%$ & 12 & $2.2 \%$ & 10 & $83.3 \%$ & 18 & $3.5 \%$ & 17 & $94.4 \%$ \\
\hline Face shield & 12 & $2.2 \%$ & 11 & $91.7 \%$ & 7 & $1.3 \%$ & 6 & $85.7 \%$ & 8 & $1.6 \%$ & 8 & $100.0 \%$ \\
\hline Other ${ }^{a}$ & 34 & $6.2 \%$ & 23 & $67.6 \%$ & 31 & $5.7 \%$ & 17 & $54.8 \%$ & 28 & $5.4 \%$ & 19 & $67.9 \%$ \\
\hline
\end{tabular}

${ }^{a_{s}}$ arf/bidon 
Respiratory Syndrome (MERS) and Severe Acute Respiratory Syndrome (SARS) infections has been reported previously [29-32]. Apprehensions about relatively high administrative penalties while not complying with governmental regulation on wearing masks could also play a role in the high percentage of those observed using masks at the beginning of this study.

Other studies found extreme variation in COVID-19related face coverings worldwide [33, 34]. As the example, in the report of the prevalence of face coverings in public places Elachola et al. found that it was almost universal in Cambodia (97\%) and Peru (86\%), however, much lower in India (41\%), Mexico (25\%) and USA (21\%); Democratic Republic of Congo showed the lowest rate $(4 \%)$ [33]. In the same vein, in a study that evaluated the uptake of non-pharmaceutical measures during the pandemic influenza A (H1N1) of 2009, participants of Asian origin had the higher facemask uptake (71\%) compared to the uptake of participants of Western or Latin American origin [35]. In many Asian countries, the SARS epidemic in 2002, the pandemic influenza A (H1N1) of 2009, along with overcrowding, dense smog and air pollution may explain the high uptake of facemasks; the transition to wearing face covering during the COVID-19 pandemic was then acceptable and easier $[33,36]$. The differences in face covering prevalence may be also attributable to variation in existence of recommendations, availability and affordability of masks, as well as delayed endorsement of masks as a COVID-19 mitigation tool [33].

The concept of collective responsibility versus personal freedom has been important in the context of face masks usage since the beginning of this pandemic. According to Gostin [37], compulsory public health prerogatives should be assessed and justified under a common ethical standard. This means individuals must pose a significant risk of spreading a dangerous infectious disease, such as SARS-Cov-2, interventions, e.g. mask use, must be likely to minimize risks, use of compulsion should be proportionate to the risk, and assessments must be based on the best available scientific evidence. In this context, in the interim guidance released on December 1st, 2020, WHO recommends that decision makers should apply a risk-based approach when considering the use of masks for the general public [13]. The relatively high face covering prevalence observed in this study may suggest that collective responsibility can take precedence over the personal freedom when the belief of potential infringement of civil liberties resulting from compulsion is counterbalanced by the potential health benefits on the population level.

The decreasing trend regarding mask usage by the general public in Poland through the 3 weeks of observation, which illustrates behavioral change, may be due to a gradual decrease in concerns about the pandemic over time and lowering in the perceived SARS-Cov-2 infection risk. Less strict supervision, monitoring and inadequate governmental regulation enforcement by the relevant services may also influence the rapid decrease in compliance rates. Although failure to comply with the government regulation could result in a fine of up to Polish zloty (PLN) 500 to PLN 30,000, according to the National Police Headquarters, between April 15th and May 31st 2020, 40,000 citizens were instructed on correct mask use; only around 13,000 were fined for not using a mask in the public space, around 5000 applications were made to the court to fine individuals for not wearing a mask [38].

Numerous examples of political leaders, including the Polish president and the prime minister not using masks in public spaces, which was transparently reported by the media [39-41], could influence mask usage by the public, by simply signaling that fears related to the virus are overblown. Public officials should be acutely aware they are in position to lead by example, with the choices they make and how they carry themselves can send a powerful message; this also refers to the SARS-Cov-2115 pandemic. Sadly, masks have become one of the potent symbols in how poorly Polish leaders have responded to this public health crisis.

\section{Determinants of mask use}

Various factors, including socio-demographic characteristics, social context and individual values can affect the subjects' perception of their actual risk of disease, as well as influence their worries about a pandemic $[3,42,43]$. Based on recent studies, being female is associated with a higher chance of adopting protective behaviors [3, 30, 44]. The results of this study show that males, traditionally risk takers, were significantly less likely to have appropriate practices regarding mask usage, and protecting themselves and others against SARS-Cov-2. These findings are consistent with other studies on SARS and MERS, showing that females are more health conscious and risk averse [30-32]. This was also reported during the current SARS-Cov-2 pandemic [45]. It is suggested that health promotion messages sent through female mediators who are significant for young males, e.g. mothers, sisters or partners, could increase mask use for this vulnerable subgroup [31].

Although not assessed in this study, younger respondents are reported as less likely to use masks in order to mitigate the chances of spreading and contracting SARS-COV-2 [46]; this might contribute to the high incidence of confirmed SARS-Cov-2 infections among that group [47]. This poses a danger not only to their peers but also to vulnerable groups, such as the elderly, those with comorbidities, people in long-term care. 
Wearing masks when out in public was significantly lower in open spaces during the three-week observation, and decreased to a greater extent (10\%) over time, when compared to enclosed spaces. During the study period government officials announced that in the upcoming weeks it would not be necessary to wear masks while walking on the street, in parks or during sport activities outdoors, e.g. riding a bike [48]; this could have influenced the behavioral change regarding the mask usage by the general public. The message that it would still be mandatory to wear masks in shops might have made the population consider its importance, which in turn influenced high compliance.

\section{Type of mask used}

To control the infection source, as well as to selfprotect, cloth masks, as recommended by the WHO, CDC, and ECDC $[13,14,16]$ are likely to be adequate to minimize SARS-Cov-2 transmission in the community, especially if everyone wears a mask correctly. Cloth masks were predominantly used in the public space in this study, possibly due to the low price and the fact that they can be easily manufactured or made at home and reused after washing. The shortage of mask supply in the community and the integrated governmental and media message that medical masks and N95 respirators must be reserved for health-care workers might have influenced their poor usage by the public.

Notably, compliance of correct mask use was poor only two thirds of those wearing masks (cloth and medical) wore them correctly at the first time point, this decreased over time, with $55 \%$ wearing cloth masks and $60 \%$ - medical ones. Although N95 respiratory masks were rarely used by the public, compliance with correct use was the best and increased over time. One of the possible interpretations of this observation could be that the potential N95 respiratory masks wearers were more health oriented and health educated. People with high health literacy skills are more competent in related to public health outbreak controls [3, 44, 49]. Due to the small number of observations regarding this type of mask usage, further qualitative and quantitative studies are needed to better assess this issue. Correct mask usage was gender dependent with more females using a mask in the proper manner. Interestingly, no differences were observed regarding the correct mask usage and residence, as well as location and type of activity.

At all 3 time points breaches in nose covering and hanging masks around the neck were the most common incorrect practices while wearing a mask. Such practices elevate infection risk regarding SARS-Cov-2 and other airborne respiratory pathogens. Notably, the pathogens may settle on the surface of used masks layers, resulting in mask contamination [50] which in turn highlights the risk of self-contamination to the wearer, particularly when fixing, elevating or doffing a mask.

\section{Strengths and limitations}

To our knowledge, this is the first study to investigate masks use in the general population in Poland, as well as in the European Union (EU). The mask usage has been assessed by a non-participatory covert observational study. Other methods to assess the uptake of facemask against respiratory infections, include observational studies (most of them standard interviewer-administered surveys) and cases series (focus groups or qualitative surveys) [36]. Nevertheless, such quantitative and qualitative studies are based on reliability of reported preventive measures taken by interviews; this may be questionable [51]. Photo-epidemiology, which involves quantification of facemasks through photo frames from surveillance camera, is a valuable method of assessing the prevalence of mask use at the population level [33, $34,52]$. With the advent of hand-held devices it can help to assess face mask use in crowds where other methods of assessment are challenging, e.g. at mass gatherings [52], at the airports [34], and at the venues such as groceries, markets and commodity food distribution centers [33]. One of the disadvantages of this method is its inadequacy to verify the type of facemask used, such as loosely fit surgical masks or fit-tested N95 masks [34].

One particular strength of this study is that participants were observed during an actual continuing outbreak - data collection started 3 weeks after an introduction of the regulation about obligatory mask use in the public space. Furthermore, by covert observation, the Hawthorne effect has been limited as the behavior of participants was not altered [53]. In addition, the method used helped to verify the type of mask used, as well as compliance of correct mask use. However, the study has some limitations which should be pointed out. Community-based national surveys were not feasible regarding the phase of SARS-Cov-2 pandemic in Poland in which the study had been conducted due to the reallocation of funds and resources to the pandemic-oriented issues. As such, data were collected through students observations, depending on their place of residence. Therefore, the majority of the participants were observed in the western and central regions of Poland, where most of the students came from. Further research should cover all Polish provinces to better assess mask usage at a national level. Due to student sick leave, the numbers of observations were smaller at the first and third time point than at the second time point. Nevertheless, the response rate was still high which led to a relatively large sample size. Another limitation is that the study was administered over a short time period. Thus, the stability of the responses is unknown [31]. Further observations 
are needed to track possible changes as the pandemic evolves. The implication is for future research to assess whether there is a relationship between mask usage and other variables, not covered by this study, such as education, knowledge on infection control, anxiety level, trust in the health authorities, etc. Finally, this study did not address causation. Therefore, the regression results should be interpreted with caution.

\section{Conclusions}

The results show an essential difference in how the general public responds to the SARS-Cov-2 pandemic in the context of mask usage. Practices were found to be inadequate, especially among males, and tended to decrease over time, more significantly among those wearing cloth masks than when compared to those wearing N95 respirators. This message can be used to target specific vulnerable groups when developing public health campaigns which should be then rigorously evaluated for their effectiveness. Among those using masks, every third individual wore them incorrectly. Therefore, awareness campaigns regarding the need for the proper usage of face masks - by utilizing all communication channels available - would be helpful during this pandemic [46]. The results may also help policy makers to adequately tailor mask usage strategies to better prevent SARS-Cov-2 transmission. Finally, political leaders should act as role models and set a good example wearing masks in the public arena to create a sense of solidarity and make a gesture with regards to evidence based practices.

In conclusion, this study identified topics that may need attitudinal modification to improve self-protection against SARS-Cov-2 infection and community spread of the virus. There is now an ideal moment to implement these adjustments.

\begin{abstract}
Abbreviations
CDC: Centers for Disease Control and Prevention; Cl: Confidence interval; COVID-19: Coronavirus Disease 2019; ECDC: European Centre for Disease Prevention and Control; EU: European Union; MERS: Middle East Respiratory Syndrome; OR: Odds ratio; PLN: Polish zloty; R: Basic reproductive number; SARS: Severe Acute Respiratory Syndrome; SARS-Cov-2: Severe Acute Respiratory Syndrome Coronavirus 2; WHO: World Health Organization
\end{abstract}

\section{Acknowledgements}

Authors want to thank all 4th year medical students of the University of Zielona Gora (UZ) who enthusiastically participated in the study. Additional thanks to Joanna Michalska and Jakub Szczepański, 4th year medical students, UZ, for their help in literature search. Special thanks to prof. Peter Barss, a Clinical Professor at the School of Population and Public Health, University of British Columbia in Vancouver, Canada, for language corrections.

\section{Authors' contributions}

MG was involved in conception and design of the study. OP made contributions to acquisition and together with $M G$ - to review of data completeness. MK together with MG, OP, DŚ and $Ł D-D$ analyzed the data. MG was involved in literature search and in drafting the manuscript, as well as - together with OP, DŚ, ŁD-D and MK - in finalizing the version to be published. All authors read and approved the final version of the manuscript.
Funding

Not applicable.

\section{Availability of data and materials}

The datasets used and/or analyzed during the current study are available from the corresponding author on reasonable request.

\section{Ethics approval and consent to participate}

In Poland there is no requirement for ethics committee (Institutional Review Board; IRB) approval for observational studies similar to ours [54]. The study was designed and conducted in accordance with these regulations and regulations established by the IRB of the University of Zielona Gora (Komisja Bioetyczna CM UZ) [55] and the 1964 Helsinki declaration [56].

The need for participant informed consent regarding observational covert studies is deemed unnecessary according to Polish national regulations [54]; covert research does not allow for the participants to give informed consent $[54,57]$.

\section{Consent for publication}

Not applicable.

\section{Competing interests}

The authors declare that they have no competing interests.

\section{Author details}

${ }^{1}$ Department of Infectious Diseases, Collegium Medicum, Uniwersytet Zielonogórski, Zielona Góra, Poland. ${ }^{2}$ Collegium Medicum, Uniwersytet Zielonogórski, Zielona Góra, Poland. ${ }^{3}$ Department of Methods of Artificial Intelligence \& Applied Mathematics, Westpomeranian University of Technology, Szczecin, Poland.

Received: 17 July 2020 Accepted: 9 February 2021

Published online: 23 February 2021

\section{References}

1. Harapan H, Itoh N, Yufika A, Winardi W, Keam S, Te H, et al. Coronavirus disease 2019 (COVID-19): a literature review. J Infect Public Health. 2020; 13(5):667-73. https://doi.org/10.1016/j.jph.2020.03.019.

2. World Health Organization. Coronavirus disease (COVID-19) dashboard. Available at: https:// covid19.who.int. Accessed: 1 December 2020.

3. Ebrahim SH, Ahmed QA, Gozzer E, Schlagenhauf P, Memish ZA. Covid-19 and community mitigation strategies in a pandemic. BMJ. 2020;368:m1066. https://doi.org/10.1136/bmj.m1066.

4. Ebrahim SH, Zhuo J, Gozzer E, Ahmed QA, Imtiaz R, Ahmed Y, et al. All hands on deck: a synchronized whole-of-world approach for COVID-19 mitigation. Int J Infect Dis. 2020;98:208-15. https://doi.org/10.1016/j.jij.2020. 06.049 .

5. Kucharski AJ, Russell TW, Diamond C, Liu Y, Edmunds J, Funk S, et al. Early dynamics of transmission and control of COVID-19: a mathematical modelling study. Lancet Infect Dis. 2020;20(5):553-8. https://doi.org/10.1016/ s1473-3099(20)30144-4.

6. Ngonghala CN, Iboi E, Eikenberry S, Scotch M, MacIntyre CR, Bonds MH, et al. Mathematical assessment of the impact of non-pharmaceutical interventions on curtailing the 2019 novel coronavirus. Math Biosci. 2020; 325:108364. https://doi.org/10.1016/j.mbs.2020.108364.

7. World Health Organization. COVID-19 strategy update. 14 April 2020. Available at: https://www.who.int/publications/i/item/covid-19-strategyupdate\%2D\%2D-14-april-2020. Accessed 12 July 2020.

8. European Observatory on Health Systems and Services. Cross countries Analyses. How are countries getting out of lockdown? Available at: https://a nalysis.covid19healthsystem.org/index. php/2020/05/ 07/how-are-countriesgetting-out-of-lockdown/ Accessed: 14 July 2020.

9. Cheng KK, Lam TH, Leung CC. Wearing face masks in the community during the COVID-19 pandemic: altruism and solidarity. Lancet. 2020;501406736(20):30918-1. https://doi.org/10.1016/S0140-6736(20)30918-1.

10. Chu DK, Duda S, Solo K, Yaacoub S, Schunemann H. Physical distancing, face masks, and eye protection to prevent person-to-person transmission of SARS-CoV-2 and COVID-19: a systematic review and meta-analysis. J Vasc Surg. 2020;72(4):1500. https://doi.org/10.1016/j.jvs.2020.07.040. 
11. World Health Organization. Advice on the use of masks in the context of COVID-19: interim guidance. 2020. Available at: https://apps.who.int/iris/ha ndle/10665/331693. Accessed 05 July 2020.

12. World Health Organization. Advice on the use of masks in the context of COVID-19: interim guidance, 2020. Available at: https://www.who.int/publica tions/i/item/advice-on-the-use-of-masks-in-the-community-during-home-ca re-and-in-healthcare-settings-in-the-context-of-the-novel-coronavirus-(2019ncov)-outbreak. Accessed 05 July 2020.

13. World Health Organization. Mask use in the context of COVID-19. Interim guidance. 2020. Available at: https://www.who.int/publications/i/item/a dvice-on-the-use-of-masks-in-the-community-during-home-care-and-in-hea Ithcare-settings-in-the-context-of-the-novel-coronavirus-(2019-ncov)-outbrea k. Accessed 2 December 2020.

14. Centers for Disease Control and Prevention. Coronavirus disease 2019 (COVID-19). Prevent getting sick. About cloth face coverings. Available at: https://www.cdc.gov/coronavirus/2019-ncov/prevent-getting-sick/about-fa ce-coverings.html Accessed 3 April 2020.

15. Esposito S, Principi N. To mask or not to mask children to overcome COVID-19. Eur J Pediatr. 2020;179(8):1267-70. https://doi.org/10.1007/s00431-020-03674-9.

16. European Centre for Disease Prevention and Control. Using face masks in the community. Stockholm: ECDC; 2020. Available at: https://www.ecdc. europa.eu/en/publications-data/using-face-masks-community-reducingcovid-19-transmission. Accessed 06 July 2020

17. European Observatory on Health Systems and Services. Cross countries Analyses. What are the policies on wearing facemasks in public places? Available at: 2020/05/22/what-are-the-policies-on-wearing-facemasks-inpublic-places/ Accessed 08 July 2020.

18. Dz.U. 2020 poz. 658. Regulation of the Council of Ministers of 10 April 2020 on the establishment of certain restrictions, orders and prohibitions in relation to the occurrence of an epidemic. Available at: https://isap.sejm.gov.pl/i sap.nsf/DocDetails.xsp?id=WDU20200000658. Accessed 10 July 2020.

19. Dz.U. 2020 poz. 964. Regulation of the Council of Ministers of 29 May 2020 on the establishment of certain restrictions, orders and prohibitions in relation to the occurrence of an epidemic. Available at: https://isap.sejm. gov.pl/isap.nsf/DocDetails.xsp?id=WDU20200000964. Accessed 12 July 2020.

20. Dz.U. 2020 poz. 1758. Regulation of the Council of Ministers of 9 October 2020 on the establishment of certain restrictions, orders and prohibitions in relation to the occurrence of an epidemic. Available at: https://isap.sejm.gov.pl/isap.nsf/DocDetails.xsp?id=WDU20200001758. Accessed 1 December 2020.

21. Gogolewski K, Rosińska M, Rabczenko D, Szczurek E, Miasojedow B, Gambin A. R estimations for Polish voivodships. Available at: https://covid19.mimuw. edu.pl/wojewodztwa_20200516.html Accessed 30 April 2020.

22. Statistics Poland. Population. Size, structure and vital statistics in Poland by territorial division. As of $30^{\text {th }}$ June 2019. Available at: https://stat.gov.pl/ obszary-tematyczne/ludnosc/ludnosc/ ludnosc-stan-i-struktura-w-przekrojuterytorialnym-stan-w-dniu-30-06-2019,6,26.html Accessed 03 July 2020.

23. RAOSOFT. Sample Size Calculator 2020. Available at: http://www.raosoft. com/samplesize.html. Accessed 10 July 2020.

24. World Health Organization. Rational use of personal protective equipment (PPE) for coronavirus disease (COVID-19): interim guidance, 2020. Available at: https://apps.who.int/ iris/handle/ 10665/331498. Accessed 6 July 2020.

25. R Development Core Team. A language and environment for statistical computing. Foundation for statistical computing. Vienna: Mining the most interesting rules; 2015. Available at: http://www.R-project.org. Accessed 28 June 2020

26. Hosmer DW, Lemeshow S. Applied Logistic Regression, vol. 95. 2nd ed. New York, Chichester, Weinheim, Brisbane, Singapore, Toronto: John Wiley \& Sons Inc.; 2000. Available at: https://onlinelibrary. wiley.com/doi/book/10. 1002/0471722146. Accessed 28 June 2020

27. Venables WN, Ripley BD. Modern applied statistics with S. 4th ed. New York: Springer; 2002. Available at: http://www.stats.ox.ac.uk/pub/MASS4. Accessed 28 June 2020

28. Hinz M. We have lost illusions. The virus is going to stay with us for longer [lpsos study]. Available at: https://oko.press/stracilismy-zludzenia-wirus-zosta nie-z-nami-dluzej-cykl-badan-ipsos/ Accessed 5 July 2020.

29. Ferng YH, Wong-McLoughlin J, Barrett A, Currie L, Larson E. Barriers to mask wearing for influenza-like illnesses among urban Hispanic households. Public Health Nurs. 2011;28:13-23. https://doi.org/10.1111/j.1 525-1446.2010.00918.x
30. Aldowyan N, Abdallah AS, El-Gharabawy R. Knowledge, Attitude and Practice (KAP) Study about Middle East Respiratory Syndrome Coronavirus (MERS-CoV) among Population in Saudi Arabia. Int Arch Med. 2017;10(254). https://doi.org/10.3823/2524

31. Leung G, Lam T, Ho L, Ho S, Chan B, Wong I, et al. The impact of community psychological responses on outbreak control for severe acute respiratory syndrome in Hong Kong. J Epidemiol Community Health. 2003; 57:857-63. https://doi.org/10.1136/jech.57.11.857.

32. Moran KR, Del Valle SY. A meta-analysis of the association between gender and protective behaviors in response to respiratory epidemics and pandemics. PLoS One. 2016;11:0164541. https:/doi.org/10.1371/journal.pone.0164541.

33. Elachola H, Gozzer E, Rahman NMM, Ditekemena J, Pando-Robles V, Pa K, et al. Photo-epidemiology to estimate face covering use in select areas in Asia versus the Americas and Africa during the COVID-19 pandemic. J Travel Med. 2020;27(8):taaa121. https://doi.org/10.1093/jtm/taaa121.

34. Elachola H, Ebrahim SH, Gozzer E, et al. Travel Med Infect Dis. 2020;35: 101637. https://doi.org/10.1016/j.tmaid.2020.101637.

35. SteelFisher GK, Blendon RJ, Ward JR, Rapoport R, Kahn EB, Kohl KS. Public response to the 2009 influenza a H1N1 pandemic: a polling study in five countries. Lancet Infect Dis. 2012;12(11):845-50. https://doi.org/10.1016/S1473-3099(12)70206-2.

36. Barasheed $\mathrm{O}$, Alfelali M, Mushta S, Bokhary $\mathrm{H}$, Alshehri J, Attar AA, et al. Uptake and effectiveness of facemask against respiratory infections at mass gatherings: a systematic review. Int J Infect Dis. 2016;47:1055-111. https:// doi.org/10.1016/j.jijid.2016.03.023.

37. Gostin LO, Hodge JG. US emergency legal responses to novel coronavirus: balancing public health and civil liberties. JAMA. 2020;323(12):1131-2. https://doi.org/10.1001/jama.2020.2025.

38. Gazeta prawna.pl. Penalties for not having a mask. 2020. Available at: https:// www.gazetaprawna.pl/artykuly/1482734,brak-maseczki-co-grozi-kara. html. Accessed 10 July 2020.

39. Kublik A. Smolensk catastrophe without masks; what are politicians allowed while others are not. Gazeta Wyborcza April 10 ${ }^{\text {th }}, 2020$. Available at: https:// wyborcza.pl/7,75398,25861336, katastrofa-smolenska-bez-masek-czyli-cowolno-wladzy-a-innym.html Accessed 30 June 2020.

40. Gazeta.pl. Andrzej Duda meeting foresters without a face mask. Your rights are better than ours? 2020. Available at: https://wiadomosci.gazeta.pl/wia domosci/7,173952,25953786, andrzej-duda-w-ogniu-krytyki-po-spotkaniu-zlesnikami-twoje.html Accessed 02 July 2020.

41. Wprost.pl. President's photo on the Instagram. Internauts point out the lack of following infection control regulations. 2020. Available at: https://info. wprost.pl/wydarzenia-dnia/10340925/ null. Accessed 03 July 2020.

42. Goodwin R, Gaines SO, Myers L, Neto F. Initial psychological responses to swine flu. Int J Behav Med. 2011;18(2):88-92. https://doi.org/10.1007/s12529-010-9083-z.

43. Vaughan $\mathrm{E}$, Tinker $\mathrm{T}$. Effective health risk communication about pandemic influenza for vulnerable populations. Am J Public Health. 2009;99(S2):S3245332. https://doi.org/10.2105/AJPH.2009.162537.

44. Bish A, Michie S. Demographic and attitudinal determinants of protective behaviors during a pandemic: a review. Br J Health Psychol. 2010;15(4):797824. https://doi.org/10.1348/135910710X485826.

45. Al-Hanawi MK, Angawi K, Alshareef N, Qattan AMN, Helmy HZ, Abudawood Y, et al. Knowledge, attitude and practice toward COVID-19 among the public in the Kingdom of Saudi Arabia: a cross-sectional study. Front Public Health. 2020:8:217. https://doi.org/10.3389/fpubh.2020.00217.

46. Hutchins HJ, Wolff B, Leeb R, Ko JY, Odom E, Willey J, et al. COVID-19 Mitigation Behaviors by Age Group — United States, April-June 2020. MMWR Morb Mortal Wkly Rep. 2020;69:1584-90. https://doi.org/10.15585/ mmwr.mm6943e4externalicon.

47. Wan W, Balingit M. WHO warns young people are emerging as main spreaders of the coronavirus. The Washington Post, 2020. Available at: https://www. washingtonpostcom/health/who-warns-young-people-areemerging-as-main-spreaders-of-the-coronavirus/2020/08/18/1822ee92-e18f11 ea-b69b-64f7b0477ed4_storyhtml Accessed 3 December 2020.

48. Medonet editors. When without masks? Obligation to cover the mouth and nose partly lifted. Available at: https://www.medonet.pl/koronawirus/korona wirus-w-polsce,kiedy-bez-maseczek\%2D\%2Dobowiazek-zaslaniania-ust-inosa-czesciowo-zniesiony,artykul,46505742.html Accessed 22 June 2020.

49. CDC. Understanding Health Literacy. Available at: https://www.cdc.gov/hea Ithliteracy/learn/ Understanding.html. Accessed 1 July 2020.

50. Chughtai AA, Stelzer-Braid S, Rawlinson W. Contamination by respiratory viruses on outer surface of medical masks used by hospital healthcare workers. BMC Infect Dis. 2019;19:491. https://doi.org/10.1186/s12879-019-4109-x. 
51. Gautret P, Vu Hai V, Sani S, Doutchi M, Parola P, Brouqui P. Protective measures against acute respiratory symptoms in French pilgrims participating in the hajj of 2009. J Travel Med. 2011;18(1):53-5. https://doi. org/10.1111/j.1708-8305.2010.00480.x.

52. Elachola H, Assiri AM, Memish ZA. Mass gathering-related mask use during 2009 pandemic influenza a (H1N1) and Middle East respiratory syndrome coronavirus. Int J Infect Dis. 2014;20:77-8. https://doi.org/10.1016/j.jijd.2 013.12.001.

53. Supehia S, Singh V, Sharma T, Khapre M, Gupta PK. Rational Use of Face Mask in a Tertiary Care Hospital Setting During COVID-19 Pandemic: An Observational Study. Indian J Public Health. 2020;64(Suppl):S225-7. https:// doi.org/10.4103/ijph.IJPH_493_20.

54. Borysowski J, Górski A. Code of Medical Ethics. Part 44: Guidelines for responsible conduct of research \& medical experiments (Kodeks Etyki Lekarskiej. Odcinek 44: Ogólne warunki przeprowadza-nia badań naukowych i eksperymentów medycznych). Available at: https:/www.mp.pl/etyka/ medycyna_eksperymentalna/179315,ogolne-warunki-przeprowadzania-bada n-naukowych-ieksperymentow-medycznych. Accessed 1 May 2020.

55. University of Zielona Gora, Collegium Medicum. Ethics Committee Regulations. https://www. cm.uz.zgora.pl/index.php?o-komisji-1.

56. Declaration of Helsinki. Ethical principles for medical research involving human subjects. Bull WHO. 2001;79(4):373-4.

57. Bryman A. Social research methods. 5th ed. Oxford: Oxford University Press; 2016

\section{Publisher's Note}

Springer Nature remains neutral with regard to jurisdictional claims in published maps and institutional affiliations.

Ready to submit your research? Choose BMC and benefit from:

- fast, convenient online submission

- thorough peer review by experienced researchers in your field

- rapid publication on acceptance

- support for research data, including large and complex data types

- gold Open Access which fosters wider collaboration and increased citations

- maximum visibility for your research: over $100 \mathrm{M}$ website views per year

At $\mathrm{BMC}$, research is always in progress.

Learn more biomedcentral.com/submissions 